\title{
Gastrointestinal tract size, total-tract digestibility, and rumen microflora in different dairy cow genotypes
}

\author{
M. Beecher, ${ }^{\star} †$ F. Buckley, ${ }^{\star}$ S. M. Waters, $\ddagger$ T. M. Boland,† D. Enriquez-Hidalgo, ${ }^{\star} \S$ M. H. Deighton, ${ }^{* 1}$ \\ M. O'Donovan, ${ }^{*}$ and E. Lewis ${ }^{* 2}$ \\ ${ }^{*}$ Teagasc, Animal \& Grassland Research and Innovation Centre, Moorepark, Fermoy, Co. Cork, Ireland \\ †School of Agriculture and Food Science, University College Dublin, Belfield, Dublin 4, Ireland \\ $\ddagger$ Teagasc, Animal \& Grassland Research and Innovation Centre, Grange, Dunsany, Co. Meath, Ireland \\ §Queen's University Belfast, Belfast, BT7 1NN, Northern Ireland
}

\begin{abstract}
The superior milk production efficiency of Jersey $(\mathrm{JE})$ and Jersey $\times$ Holstein-Friesian $(\mathrm{JE} \times \mathrm{HF})$ cows compared with Holstein-Friesian (HF) has been widely published. The biological differences among dairy cow genotypes, which could contribute to the milk production efficiency differences, have not been as widely studied however. A series of component studies were conducted using cows sourced from a longer-term genotype comparison study (JE, JE $\times \mathrm{HF}$, and $\mathrm{HF}$ ). The objectives were to (1) determine if differences exist among genotypes regarding gastrointestinal tract (GIT) weight, (2) assess and quantify whether the genotypes tested differ in their ability to digest perennial ryegrass, and (3) examine the relative abundance of specific rumen microbial populations potentially relating to feed digestibility. Over $3 \mathrm{yr}$, the GIT weight was obtained from $33 \mathrm{HF}, 35 \mathrm{JE}$, and $27 \mathrm{JE} \times \mathrm{HF}$ nonlactating cows postslaughter. During the dry period the cows were offered a perennial ryegrass silage diet at maintenance level. The unadjusted GIT weight was heavier for the $\mathrm{HF}$ than for $\mathrm{JE}$ and $\mathrm{JE} \times \mathrm{HF}$. When expressed as a proportion of body weight $(\mathrm{BW}), \mathrm{JE}$ and $\mathrm{JE} \times \mathrm{HF}$ had a heavier GIT weight than HF. In vivo digestibility was evaluated on 16 each of JE, JE $\times \mathrm{HF}$, and HF lactating dairy cows. Cows were individually stalled, allowing for the total collection of feces and were offered freshly cut grass twice daily. During this time, daily milk yield, BW, and dry matter intake (DMI) were greater for $\mathrm{HF}$ and JE $\times$ HF than for JE; milk fat and protein concentration ranked oppositely. Daily milk solids yield did not differ among the 3 genotypes. Intake capacity, expressed as DMI per BW, tended to be different among treatments, with JE having the greatest DMI
\end{abstract}

Received November 12, 2013

Accepted February 11, 2014.

${ }^{1}$ Present address: Future Farming Systems Research Division, Department of Environment and Primary Industries, Ellinbank, Victoria 3821, Australia.

${ }^{2}$ Corresponding author: eva.lewis@teagasc.ie per BW, HF the lowest, and JE $\times$ HF being intermediate. Production efficiency, expressed as milk solids per DMI, was higher for JE than HF and JE $\times$ HF. Digestive efficiency, expressed as digestibility of dry matter, organic matter, N, neutral detergent fiber, and acid detergent fiber, was higher for JE than HF. In grazing cows ( $\mathrm{n}=15$ per genotype) samples of rumen fluid, collected using a transesophageal sampling device, were analyzed to determine the relative abundance of rumen microbial populations of cellulolytic bacteria, protozoa, and fungi. These are critically important for fermentation of feed into short-chain fatty acids. A decrease was observed in the relative abundance of Ruminococcus flavefaciens in the JE rumen compared with $\mathrm{HF}$ and $\mathrm{JE} \times \mathrm{HF}$. We can deduce from this study that the JE genotype has greater digestibility and a different rumen microbial population than HF. Jersey and JE $\times \mathrm{HF}$ cows had a proportionally greater GIT weight than HF. These differences are likely to contribute to the production efficiency differences among genotypes previously reported.

Key words: digestibility, breed, rumen microflora, production efficiency

\section{INTRODUCTION}

The topic of production efficiency, within the context of livestock production systems, has received renewed attention in recent years (Spurlock et al., 2012; Berry and Crowley, 2013; Connor et al., 2013). The great debate concerning land use for ruminant production versus production of human edible feed is a primary driver for this renewed interest in production efficiency (Wilkinson, 2011). Opportunities to directly select for improved efficiency are limited, as DMI measurements from individual cows, required to generate breeding values for traits related to efficiency, are not routinely available. However, genetic diversity within feed efficiency has been demonstrated to exist. In a review of genetic parameters for the trait, Berry and Crowley (2013) reported heritability estimates for feed 
efficiency-related traits in cows (residual feed intake or feed conversion ratio) ranging from 0.00 (Svendsen et al., 1993) to 0.38 (Veerkamp et al., 1995). A review by Goddard and Grainger (2004), and more recently studies by Buckley et al. (2007) and Prendiville et al. (2011a), indicated genotype or strain within genotype variation for DMI capacity and milk production efficiency. Milk production efficiency can be defined in many ways. The present study uses the definition of milk solids yield (kilograms of fat and protein) per unit of DMI (Lopez-Villalobos et al., 2008). Whereas such variation in milk production efficiency has been demonstrated, the biological differences among dairy cow genotypes, which could contribute to the milk production efficiency differences measured, have not been as widely studied. Previous studies are either dated or use beef cattle (Smith and Baldwin, 1974; Richardson and Herd, 2004). Hence, further evidence of biological differences among the genotypes is warranted to enhance the understanding of the production efficiency differences and the potential to select for this increasingly important trait.

Prendiville et al. (2010) concluded that differences in grazing behavior contributed little to differences in DMI capacity among lactating dairy cow genotypes. They speculated that the higher DMI capacity expressed as DMI per BW observed with Jersey $(\mathbf{J E})$ and Jersey $\times$ Holstein-Friesian $(\mathbf{J E} \times \mathbf{H F})$ compared with Holstein-Friesian (HF) was likely a function of physical differences associated with gastrointestinal tract (GIT) size. Two studies exist that support this speculation, but their relevance in the context of modern HF and $\mathrm{JE}$ genetics is questionable, as one study is almost 40 yr old (Smith and Baldwin, 1974) and the other (Nagel and Piatkowski, 1988) compared JE to German BlackPied cattle. Both studies are limited by very small numbers of lactating animals and neither compared the genotypes consuming a grass-based diet.

Differences in digestibility among beef steers are reported to account for $10 \%$ of the variation in feed efficiency, with more efficient animals capable of digesting more of the diet (Richardson and Herd, 2004). Genetic variation among dairy cows in their ability to digest a predominately grazed grass diet ranges from 0.08 to 0.45 , but digestibility was predicted using the n-alkane method (Berry et al., 2007). The accuracy of the n-alkane method is questionable, as errors can arise from estimation of the alkane concentration, herbage sampling errors, or analytical errors (Rymer, 2000). Digestibility measured in vivo is the most accepted method. Digestibility and DMI are related, as increasing DMI can result in a quicker passage rate (Thornton and Minson, 1972; Colucci et al., 1982) resulting in decreased digestibility (Tyrrell and Moe, 1975). Yet JE animals have been shown to have both a greater DMI capacity (Goddard and Grainger, 2004; Prendiville et al., 2009) and a higher NDF digestibility than HF cows, resulting in JE producing a greater milk energy output per kilogram of DMI (Aikman et al., 2008). However, animals in the latter study were offered a TMR diet. Differences in digestibility among dairy cows offered a predominately grass-based diet warrants further research to accurately determine the digestibility differences in vivo among genotypes.

Approximately $65 \%$ of digestion occurs in the rumen (Hogan and Weston, 1967). Rumen microorganisms control rumen $\mathrm{pH}$ (Williams and Coleman, 1997) and the fermentation of cellulose, hemicellulose, and fiber into short-chain FA (Van Soest, 1994; Gordon and Phillips, 1998), which are used by the host for maintenance, growth, and performance. Previous work has shown that diet has a large influence on the rumen microbial population, affecting the bacteria (e.g., Bacteroidetes and Firmicutes) and archaeal populations (de Menezes et al., 2011), whereas the cellulolytic bacteria (e.g., Fibrobacter succinogenes, Ruminococcus flavefaciens, and Ruminococcus albus) are affected more by the individual host cow than by diet (Weimer et al., 1999). Data suggest that variation in feed efficiency in beef cattle may be explained by rumen microbial density and diversity (Guan et al., 2008; Carberry et al., 2012). However, no information is available comparing the rumen microbial populations among dairy cow genotypes consuming a grass diet. The objectives of the present study were to (1) determine if differences exist among dairy cow genotypes regarding GIT weight, (2) assess if JE, and by extension $\mathrm{JE} \times \mathrm{HF}$, differ from $\mathrm{HF}$ in their ability to digest perennial ryegrass, and (3) examine the relative abundance of specific rumen microbial populations potentially relating to feed digestibility among dairy cow genotypes.

\section{MATERIALS AND METHODS}

All sampling procedures described as part of the present experiment were executed in accordance with guidelines set by the Irish Minister for Health and Children under section 8 of the Cruelty to Animals Act (1876). This study comprised a series of component studies conducted using cows sourced from a longer term genotype comparison study $(\mathrm{JE}, \mathrm{JE} \times \mathrm{HF}$, and HF) based at the Teagasc, Animal and Grassland Research and Innovation Centre, Moorepark, Fermoy, Co. Cork, Ireland $\left(52^{\circ} 09^{\prime} \mathrm{N} ; 8^{\circ} 16^{\prime} \mathrm{W}\right)$. The longer term study was established in 2006 to evaluate the performance and profit potential of JE, JE $\times \mathrm{HF}$, and $\mathrm{HF}$ under an 
Irish grass-based production system (Prendiville et al., 2011b). Until 2009, the 3 genotypes grazed as a single herd, at which point the study was redesigned to implement treatments that would determine if performance differences existed at different stocking rates (genotype $\times$ environment; $\mathrm{G} \times \mathrm{E}$ ) (Thackaberry et al., 2011). It was during this later stage in the research program that the series of component studies presented were conducted.

\section{Postslaughter Anatomical Data}

Over a 2-yr period, on dates approximating to the end of the 3 experimental seasons 2009 to 2011, a total of 95 nonpregnant cows were slaughtered and had weights recorded for a range of tissues and organs associated with DMI and metabolic activity in the dairy cow, including reticulorumen, abomasum, omasum, intestines, heart, lungs, pancreas, liver, kidneys, and weight of cold carcass. Cows were slaughtered over 2 d during February 2010, December 2010, and November 2011. During February 2010, December 2010, and November 2011, the cows slaughtered comprised $10 \mathrm{JE}, 8 \mathrm{JE} \times \mathrm{HF}$, and $12 \mathrm{HF} ; 14 \mathrm{JE}, 8 \mathrm{JE} \times \mathrm{HF}$, and $13 \mathrm{HF}$; and $11 \mathrm{JE}, 11 \mathrm{JE} \times \mathrm{HF}$, and $8 \mathrm{HF}$ cows, respectively. The mean (SD) parity of $\mathrm{JE}, \mathrm{JE} \times \mathrm{HF}$, and HF cows were 3.0 (1.21), 3.3 (1.22) and 3.3 (1.29), respectively. All cows were dry at time of slaughter and were managed similarly from dry-off to slaughter and offered a maintenance diet of perennial ryegrass silage. The average number of days dry within each genotype were 23 (22.7), 22 (22.3), and $27 \mathrm{~d}$ (22.1) for JE, JE $\times \mathrm{HF}$, and HF, respectively. Animals were not fasted before slaughter (Dawn Meats, Charleville, Co. Cork, Ireland). Individual cow BW on arrival at the slaughter factory was recorded. Animals were stunned by captive bolt pistol, hung, and bled. The slaughter of animals during this study complied with Statutory Instruments (S.I.) No. 328/1999 (Abattoirs Act, 1988 Regulations, 1999).

All organs and tissues were removed and weighed (CPWplus35M, P.J. Boner and Co. Ltd., Dublin 12, Ireland) within 60 min of slaughter. Adipose tissue was removed from the kidneys, liver, lungs, and pancreas before weighing. The components of the GIT were separated and excess adipose tissue on the reticulorumen, omasum, and abomasum was removed before weighing. The reticulorumen and abomasum were cleaned of digesta residues before weighing. The omasum and small and large intestines (hereafter referred to as intestines) were weighed as presented. Total GIT weight was calculated as the sum of the reticulorumen, omasum, abomasum, and intestines weights.

\section{In Vivo Digestibility Trials}

In vivo digestibility trials on 16 each of $\mathrm{JE}, \mathrm{JE} \times$ $\mathrm{HF}$, and HF lactating dairy cows were conducted over 4 consecutive time periods balanced for genotype. The study commenced on August 3 and finished on September 24, 2010. At the beginning of the study, the mean BW of JE, JE $\times$ HF, and HF cows were 434 (39.3), 501 (40.6), and $576 \mathrm{~kg}$ (44.7), respectively. The mean parity of JE, JE $\times \mathrm{HF}$, and HF cows were 3.8 (1.06), 3.6 (1.31), and 3.3 (1.24), respectively. The mean DIM of $\mathrm{JE}, \mathrm{JE} \times \mathrm{H}$, and HF cows were 167 (26.7), 180 (21.0), and 170 (22.7), respectively.

Each time period, consisting of $12 \mathrm{~d}$, was conducted in a similar manner. Cow BW was measured the day before the animals entered the metabolism house and on the day they entered the metabolism house. Body weight was recorded using electronic portable weighing scales and the Winweigh software package (Tru-test Limited, Auckland, New Zealand).

During the study, the cows were individually stalled, offered fresh cut perennial ryegrass twice daily at 0800 and $1400 \mathrm{~h}$, and had ad libitum access to water. Grass was cut before each feeding time using a Pottinger Nova cat 266 F mower (Alois Pöttinger Maschinenfabrik GmBH, Grieskirchen, Germany) and transported using a Pottinger Europrofi 1 Euromatic self-loading wagon (Alois Pöttinger Maschinenfabrik GmBH). Two herbage allowances were used: high and low. The HF and JE $\times$ HF cows on the high herbage allowance were offered $20 \mathrm{~kg}$ of $\mathrm{DM} /$ cow per day and JE cows on the high herbage allowance were offered $17 \mathrm{~kg}$ of $\mathrm{DM} /$ cow per day. The HF and JE $\times$ HF cows on the low herbage allowance were offered $16 \mathrm{~kg}$ of $\mathrm{DM} /$ cow per day and JE cows on the low herbage allowance were offered $14 \mathrm{~kg}$ of DM/cow per day. The low and high herbage allowances offered were to reflect treatments from which the animals were randomly selected (i.e., high and low stocking rates) as described by Thackaberry et al. (2011). Pre- and postcutting sward heights were determined daily using a plate meter with a steel plate (diameter $355 \mathrm{~mm}$ and $3.2 \mathrm{~kg} / \mathrm{m}^{2}$; Jenquip, Fielding, New Zealand).

Following a 6-d acclimatization period, a 6-d measurement period began during which individual total DMI and feces production was recorded daily (Raymond et al., 1953). A representative sample of the grass offered was collected daily during the 6-d measurement period. Refused herbage was weighed back and recorded each morning for each cow during the measurement period. Total weight of feces produced by each cow was recorded daily and a $1 \%$ subsample was retained. 
Herbage Samples. Dry matter was determined by drying herbage at $95^{\circ} \mathrm{C}$ for $15 \mathrm{~h}$. Further herbage samples were stored at $-20^{\circ} \mathrm{C}$ before being freeze-dried (LS40+Chamber, MechaTech Systems Ltd., Bristol, $\mathrm{UK})$ at $-55^{\circ} \mathrm{C}$ for chemical analysis. The freeze-dried samples were milled through a 1-mm screen (Cyclotech 1093, Foss, DK-3400 Hillerød, Denmark). Samples were analyzed for ash content by placing samples into a Gallenkamp muffle furnace size 3 (Thermo Fisher Scientific INC., Waltham, MA) for $16 \mathrm{~h}$ at $500^{\circ} \mathrm{C}$ (AOAC International, 1995; method 942.05). The CP concentration of the samples was analyzed using a Leco $\mathrm{N}$ analyzer (Leco FP-528; Leco Corporation, St., Joseph, MI). The samples were analyzed for NDF and ADF with an Ankom Fiber Analyzer (Ankom Technology Corporation, Macedon, NY) using the method of Van Soest et al. (1991). Amylase and sulfite were used in the NDF process. The NDF and ADF values are expressed excluding ash.

Fecal Samples. Fecal samples were frozen at $-20^{\circ} \mathrm{C}$ and stored until the end of the study. The frozen samples were thawed before drying at $60^{\circ} \mathrm{C}$ for $48 \mathrm{~h}$ and subsequently milled through a 1-mm screen. Following milling, the daily fecal samples were composited by cow within measurement period. Fecal samples were analyzed for DM, ash, N, NDF, and ADF concentration using the methods for herbage samples described previously.

Milk Production. Cows were milked twice daily (0800 and $1600 \mathrm{~h})$ and individual cow milk yield was recorded (Dairymaster, Causeway, Co. Kerry, Ireland) at each milking. Milk fat, protein, and lactose concentrations were determined with the Milkoscan 203 (DK-3400; Foss) from 1 successive evening (Tuesday) and morning (Wednesday) milk sample for each cow during each measurement period. Daily milk solids yield $(\mathrm{kg} / \mathrm{d})$ was calculated as the sum of fat $(\mathrm{kg})$ plus protein $(\mathrm{kg})$ for each cow.

Digestibility Calculations. Apparent digestibility was calculated using Equation 1:

$$
\text { Digestibility }=\frac{(x-y)}{x},
$$

where $x$ and $y$ are equal to the intake in herbage and the output in feces of the relevant component, respectively. This equation was used to calculate the apparent digestibility for DM, OM, N, NDF, and ADF.

\section{Abundance of Selected Rumen Microbes}

A third component study was undertaken in late September 2010 to examine the relative abundance of specific rumen microbial populations potentially involved in cellulose digestion. For the present study, a further 15 of each $\mathrm{HF}, \mathrm{JE}$, and $\mathrm{JE} \times \mathrm{HF}$ cows that were part of the genotype $\times$ stocking rate study mentioned above and described briefly by Thackaberry et al. (2011) were sampled. These cows were grazing pasture and not the same cows used in the in vivo digestibility study. The mean parity of JE, JE $\times \mathrm{HF}$, and $\mathrm{HF}$ cows were 2.9 (1.55), 2.9 (1.58), and 2.7 (1.50), respectively. Samples of rumen fluid from cows were collected after morning milking using the transesophageal sampling device (FLORA rumen scoop, Guelph, ON, Canada), as described by Geishauser et al. (2012). The scoop was inserted and allowed to settle in the rumen, after $1 \mathrm{~min}$ the scoop was opened for 1 min to collect fluid then closed and removed. This procedure was designed to avoid contamination with saliva.

A 20-mL aliquot of the collected rumen fluid was transferred using a pipette and sterilized tip into a separate labeled sterilized container, immediately frozen in liquid $\mathrm{N}$ and stored at $-80^{\circ} \mathrm{C}$ until processing. Total microbial DNA was extracted from rumen fluid samples by adaptation of the repeated bead beating and column purification $(\mathrm{RBB}+\mathrm{C})$ method $(\mathrm{Yu}$ and Morrison, 2004), which provides efficient recovery of PCR-quality microbial DNA (Carberry et al., 2012). The integrity of microbial DNA and successful removal of RNA were verified by agarose gel electrophoresis. The concentration and quality of DNA was determined at $A_{260 \mathrm{~nm}}$ and $A_{280 \mathrm{~nm}}$ with a NanoDrop ND-1000 Spectrophotometer (NanoDrop Technologies, Wilmington, $\mathrm{DE})$.

Quantitative real-time PCR (qPCR) assays were performed to measure the relative abundance of several rumen microbial populations potentially involved in cellulose digestion; namely, protozoa, anaerobic fungi, and cellulolytic and fibrolytic bacteria, F. succinogenes and $R$. flavefaciens, as described by Carberry et al. (2012). Genus- or species-specific primer sets used in the current study to amplify genus- and species-specific partial 16S ribosomal RNA and $18 \mathrm{~S}$ ribosomal RNA gene regions are presented in Table 1. All primer sets were commercially synthesized (Sigma-Aldrich Ireland Ltd., Dublin, Ireland), and end-point PCR was conducted to validate the specificity of the primers against target species. Aliquots of $10 \mu \mathrm{L}$ of PCR products were analyzed by electrophoresis on a $2 \%$ agarose gel (wt/ vol) to verify the presence and size of the amplicons. Negative controls without template DNA were included in parallel. Amplicons corresponding to specific microbial groups were subjected to sequence analysis to verify their primer-specific identity (Macrogen, Seoul, Korea).

Relative qPCR assays were performed on an ABI 7500 Fast Real-Time PCR system using Fast Power 


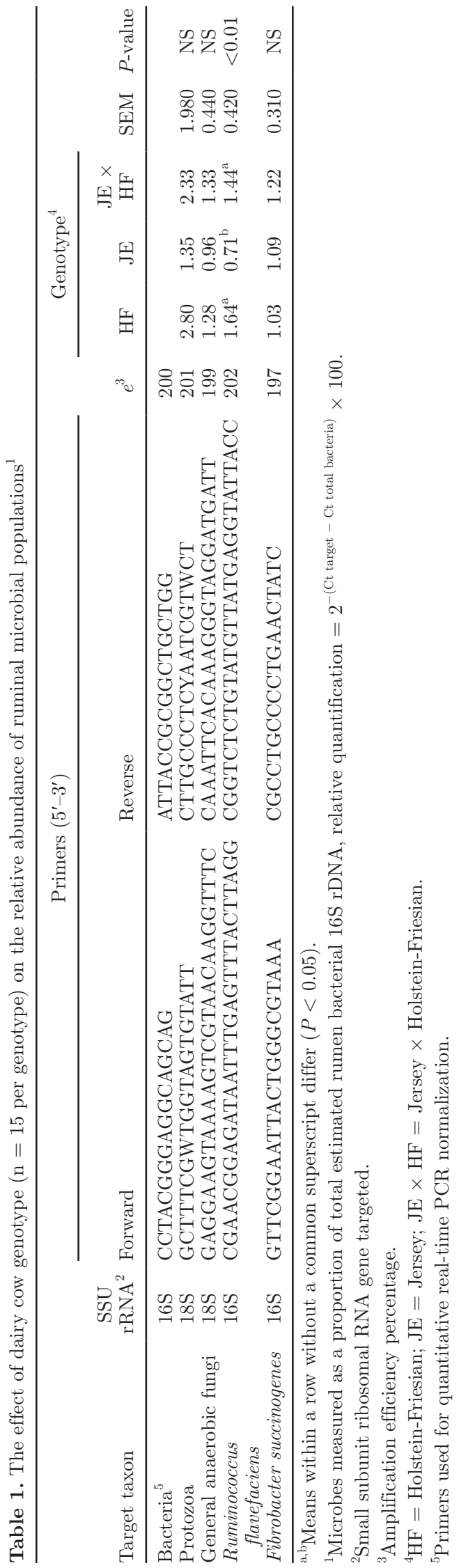

SYBR Master Mix (Applied Biosystems, Warrington, UK), as described by Carberry et al. (2012). Optimization of assay conditions were performed for both primer and template DNA concentrations. To reduce PCR inhibition, total microbial DNA was diluted to $1 \mathrm{ng} /$ $\mu \mathrm{L}$. A primer concentration of $10 \mu M$ was found to be optimal for each assay. Real-time PCR amplification efficiencies $(e)$ were estimated for the primer sets from a linear regression of the threshold cycle $(\mathrm{Ct})$ for each dilution versus the log dilution using the formula $e=\mathrm{x}^{-1 / \text { slope }}$, where $\mathrm{x}=$ fold dilution (Pfaffl, 2001). Efficiencies of the primers sets are presented in Table 1. These efficiencies ranged from 197 to $201 \%$, close to the optimum value of $200 \%$, which is representative of the doubling effect of the target sequence during the qPCR cycle. Adhering to the Minimum Information for Publication of Quantitative Real-Time PCR Experiments (MIQE) guidelines (Bustin et al., 2009), qPCR data was processed using the software package GenEx 5.2.1.3 (MultiD Analyses AB, Gothenburg, Sweden), as previously described (O'Loughlin et al., 2011). Changes in microbial communities due to genotype were expressed relative to total bacteria. Specifically, abundance of microbial populations were expressed as a proportion of total estimated rumen bacterial $16 \mathrm{~S}$ rDNA, as described previously (Chen et al., 2008; Guo et al., 2008) according to the equation: relative quantification $=2^{-(\mathrm{Ct} \text { target }-\mathrm{Ct} \text { total bacteria })}$ (Carberry et al., 2012).

\section{Statistical Analysis}

All data were statistically analyzed using SAS (SAS Institute Inc., Cary, NC). In the first component study, heart, lungs, liver, and kidney data were analyzed $(\mathrm{n}=$ 83), and pancreas, reticulorumen, omasum, abomasum, intestines, and total GIT data were also analyzed (n $=77$ ). Some data were excluded from analysis as the scales malfunctioned on one of the days of slaughter. All data $(\mathrm{n}=95)$ were available for statistical analysis of metabolic BW. Organ mass was expressed as grams per kilogram of BW and was analyzed using PROC GLM. Genotype, day of slaughter, parity, and all interactions were included in the model. In the second component study, herbage composition data during the in vivo digestibility trials were analyzed using PROC GLM. Time period was included as the fixed effect in the model. Time period refers to the weeks of the 4 digestibility trials (weeks beginning August 2, August 16, August 30, and September 13). Milk yield, fat and protein concentration, and milk solids yield data were analyzed using PROC GLM. Genotype, herbage allowance, time period, and all interactions among genotype, herbage allowance, and time period were included as 
Table 2. The effect of dairy cow genotype on BW and mass of body components from cows slaughtered in February 2010, December 2010, and November 2011

\begin{tabular}{lccccc}
\hline & \multicolumn{5}{c}{ Genotype $^{1}$} \\
Variable $(\mathrm{kg})$ & $\mathrm{HF}$ & $\mathrm{JE}$ & $\mathrm{JE} \times \mathrm{HF}$ & SEM & $P$-value \\
\cline { 2 - 5 } BW & $557^{\mathrm{a}}$ & $406^{\mathrm{c}}$ & $486^{\mathrm{b}}$ & 7.9 & $<0.001$ \\
Heart & $2.3^{\mathrm{a}}$ & $2.0^{\mathrm{b}}$ & $2.2^{\mathrm{a}}$ & 0.05 & $<0.001$ \\
Lung & $5.4^{\mathrm{a}}$ & $4^{\mathrm{b}}$ & $4.8^{\mathrm{b}}$ & 0.16 & $<0.001$ \\
Pancreas & $0.8^{\mathrm{b}}$ & $0.8^{\mathrm{a}}$ & $0.8^{\mathrm{a}}$ & 0.02 & NS \\
Liver & $7.7^{\mathrm{a}}$ & $6.2^{\mathrm{b}}$ & $7.4^{\mathrm{a}}$ & 0.17 & $<0.001$ \\
Kidney & $1.5^{\mathrm{a}}$ & $1.1^{\mathrm{c}}$ & $1.4^{\mathrm{b}}$ & 0.03 & $<0.001$ \\
Reticulorumen & $13.5^{\mathrm{a}}$ & $11.7^{\mathrm{b}}$ & $13.8^{\mathrm{a}}$ & 0.38 & $<0.001$ \\
Omasum & $16.1^{\mathrm{a}}$ & $13.8^{\mathrm{b}}$ & $15.5^{\mathrm{a}}$ & 0.44 & $<0.001$ \\
Abomasum & $4.0^{\mathrm{a}}$ & $3.3^{\mathrm{b}}$ & $3.6^{\mathrm{ab}}$ & 0.20 & $<0.05$ \\
Intestine & $37.3^{\mathrm{a}}$ & $28.7^{\mathrm{b}}$ & $33.0^{\mathrm{c}}$ & 0.91 & $<0.001$ \\
Total GIT & $71.2^{\mathrm{a}}$ & $57.2^{\mathrm{c}}$ & $66.2^{\mathrm{b}}$ & 1.55 & $<0.001$ \\
\hline
\end{tabular}

${ }^{\mathrm{a}-\mathrm{c}}$ Means within a row without a common superscript differ $(P<0.05)$.

${ }^{1} \mathrm{HF}=$ Holstein-Friesian $(\mathrm{n}=33) ; \mathrm{JE}=$ Jersey $(\mathrm{n}=35) ; \mathrm{JE} \times \mathrm{HF}=$ Jersey $\times$ Holstein-Friesian $(\mathrm{n}=27)$.

${ }^{2}$ Total GIT (gastrointestinal tract) $=$ sum of reticulorumen, omasum, abomasum, intestines.

fixed effects in the model. Intake and digestibility data were analyzed using PROC MIXED with individual cow as the random variable. Genotype, time period, herbage allowance, and all interactions were included as fixed effects in the model. In the third component study, PROC MIXED was used to determine the effect of genotype on the relative abundance of rumen microbial populations with the individual cow as the random variable and genotype as the fixed effect in the model. For all data, the Tukey-Kramer multiple range test was used for mean separation $(P<0.05)$.

\section{RESULTS}

\section{Abundance of Selected Rumen Microbes}

Table 1 shows the relative abundance of rumen microbial populations in grazing $\mathrm{HF}, \mathrm{JE}$, and $\mathrm{JE} \times \mathrm{HF}$ cows. No significant differences were observed in the relative abundance of bacteria, protozoa, general anaerobic fungi, and F. succinogenes populations among genotypes. A decrease was noted in the relative abundance of $R$. flavefaciens in the rumen microflora of JE compared with $\mathrm{HF}$ and $\mathrm{JE} \times \mathrm{HF}$ cows $(P<0.001)$.

\section{Postslaughter Anatomical Data}

A genotype effect on BW and the unadjusted anatomical data was observed (Table 2). The HF were heavier than both $\mathrm{JE}$ and $\mathrm{JE} \times \mathrm{HF}(P<0.001)$. The HF had a heavier heart, lungs, liver, kidneys, reticulorumen, omasum, abomasum, intestines, and total GIT compared with the JE $(P<0.01)$. The HF had heavier lungs, kidneys, intestines, and total GIT compared with the $\mathrm{JE} \times \mathrm{HF}(P<0.05)$. No difference in abomasal weight or in lungs and pancreas weights was observed between JE and $\mathrm{JE} \times \mathrm{HF}(P>0.05)$. A genotype effect was seen on anatomical data normalized to BW (Table 3 ) except for liver, kidneys, and intestines $(P>0.05)$. On a per-unit BW basis, HF had a lighter heart, lungs, pancreas, reticulorumen, omasum, and total GIT than JE $(P<0.05)$. No difference was noted in lungs or omasum weights between $\mathrm{HF}$ and $\mathrm{JE} \times \mathrm{HF}(P>0.05)$. The JE $\times$ HF had a proportionally heavier heart, pancreas, reticulorumen, and total GIT compared with the HF $(P<0.001)$. No difference was observed between the JE and JE $\times$ HF in kidney, liver, lungs, reticulorumen, omasum, intestines, and total GIT $(P>0.05)$.

\section{In Vivo Digestibility Trials}

Herbage Composition and Herbage Measurements. The average precutting sward height of the harvested herbage offered during each of the 4 time periods was 14.9 (0.80), $9.2(0.53), 15.4$ (1.08), and 11.1 $\mathrm{cm}$ (1.50), respectively. The average postcutting sward heights were 5.2 (0.62), $4.3(0.44), 4.5(0.29)$ and 4.4 $\mathrm{cm}(0.95)$, respectively. The average regrowth interval for the swards were 23 (2.1), 20 (0.9), 23 (0.0) and 17 d (4.6), respectively. The chemical composition of the herbage offered to the cows during the 4 time periods is shown in Table 4.

Milk Production. With the exception of milk solids yield, a genotype effect was observed on all milk parameters recorded $(P<0.01$; Table 5$)$. The HF cows had the highest milk yield, JE had the lowest, and JE $\times$ HF were intermediate $(P<0.001)$. Milk fat and protein concentration was highest for the JE, lowest for the $\mathrm{HF}$, and $\mathrm{JE} \times \mathrm{HF}$ were intermediate $(P<0.001)$. Similarly, kilograms of milk solids per 100 kilograms of BW were highest for the JE, lowest for the HF, and JE $\times$ HF were intermediate $(P<0.001)$. 
Table 3. The effect of dairy cow genotype on mass of body components expressed on a per-unit BW basis from cows slaughtered in February 2010, December 2010, and November 2011

\begin{tabular}{|c|c|c|c|c|c|}
\hline \multirow{2}{*}{$\begin{array}{l}\text { Variable } \\
(\mathrm{g} / \mathrm{kg} \text { of } \mathrm{BW})\end{array}$} & \multicolumn{3}{|c|}{ Genotype $^{1}$} & \multirow[b]{2}{*}{ SEM } & \multirow[b]{2}{*}{$P$-value } \\
\hline & $\mathrm{HF}$ & $\mathrm{JE}$ & $\mathrm{JE} \times \mathrm{HF}$ & & \\
\hline Heart & $4.1^{\mathrm{c}}$ & $5.0^{\mathrm{a}}$ & $4.6^{\mathrm{b}}$ & 0.10 & $<0.001$ \\
\hline Lungs & $9.7^{\mathrm{b}}$ & $11.0^{\mathrm{a}}$ & $10.1^{\mathrm{ab}}$ & 0.36 & $<0.05$ \\
\hline Pancreas & $1.5^{\mathrm{c}}$ & $1.8^{\mathrm{a}}$ & $1.7^{\mathrm{b}}$ & 0.04 & $<0.001$ \\
\hline Liver & 13.8 & 13.3 & 13.3 & 0.30 & NS \\
\hline Kidney & 2.6 & 2.7 & 2.8 & 0.07 & NS \\
\hline Reticulorumen & $24.3^{\mathrm{b}}$ & $29.3^{\mathrm{a}}$ & $28.3^{\mathrm{a}}$ & 0.79 & $<0.001$ \\
\hline Omasum & $29.2^{\mathrm{b}}$ & $33.9^{\mathrm{a}}$ & $31.8^{\mathrm{ab}}$ & 0.86 & $<0.001$ \\
\hline Abomasum & 7.2 & 8.2 & 7.5 & 0.38 & 0.09 \\
\hline Intestines & 67.1 & 70.1 & 68.3 & 1.67 & NS \\
\hline Total GIT ${ }^{2}$ & $128.8^{\mathrm{b}}$ & $142.5^{\mathrm{a}}$ & $136.8^{\mathrm{a}}$ & 2.87 & $<0.001$ \\
\hline
\end{tabular}

An effect of herbage allowance on milk production was noted. Milk yield and milk solids yield were higher for the cows offered the high herbage allowance $(16.2$ \pm 0.31 and $1.6 \pm 0.03 \mathrm{~kg}$, respectively) than the cows offered the low herbage allowance $(14.2 \pm 0.31$ and 1.4 $\pm 0.03 \mathrm{~kg}$, respectively; $P<0.01$ ). No effect of herbage allowance on milk fat and protein concentration was observed.

Herbage Intake and Milk Solids per Kilogram of DMI. Genotype had a significant effect on all grass intake parameters investigated $(P<0.05$; Table 6$)$. The JE $\times$ HF and HF consistently had a higher intake of DM, OM, N, NDF, and ADF than the JE $(P<0.05$; Table 6). Intake (DM/100 kg of BW) tended to be different among treatments and was numerically highest for JE and lowest for HF. The JE cows had a higher yield of milk solids per kilogram of DMI than HF and JE $\times$ HF cows (Table $6 ; P<0.01$ ). Although numerically in favor of JE $\times \mathrm{HF}$, no significant difference was seen between $\mathrm{HF}$ and $\mathrm{JE} \times \mathrm{HF}$ regarding milk solids per kilogram of DMI $(P>0.05)$.

An effect of herbage allowance on herbage intake was observed. Dry matter intake was higher for the cows offered the high herbage allowance $(16.3 \mathrm{~kg} \pm 0.13)$ than the cows offered low herbage allowance (14.8 \pm $0.13 \mathrm{~kg} ; P<0.001)$.
Herbage Digestibility. For all digestibility parameters investigated, JE cows had a higher digestibility than HF cows $(P<0.05$; Table 7$)$. The $\mathrm{JE} \times \mathrm{HF}$ cows were intermediate to $\mathrm{HF}$ and $\mathrm{JE}$ cows for all parameters except for DM digestibility. The DM digestibility of $\mathrm{HF}$ and $\mathrm{JE} \times \mathrm{HF}$ cows was similar $(P>0.05)$. Jersey cows were able to digest $2.2 \%$ more DM than both HF and JE $\times$ HF cows. No effect of herbage allowance was seen on any of the digestibility parameters investigated $(P>0.05)$.

\section{DISCUSSION}

The present study investigated GIT weight, apparent total-tract digestibility, and rumen microbial population composition to determine if differences existed among dairy cow genotypes. Previous research has proven that JE and JE $\times$ HF are highly efficient milk producers (Prendiville et al., 2011a; Vance et al., 2012). Total-tract digestibility, GIT size, and rumen microbial populations are factors that may contribute to production efficiency (Richardson and Herd, 2004).

Dry matter intake is affected by several factors. Reviews by Allison (1985) and Allen (1996) suggest that one factor limiting DMI is GIT capacity and, in particular, the capacity of the reticulorumen. Rumen

Table 4. The chemical composition of grass offered to Holstein-Friesian, Jersey, and Jersey $\times$ Holstein-Friesian lactating dairy cows during in vivo digestibility studies conducted on 4 occasions in 2010 (weeks beginning August 8, August 22, September 5, September 19)

\begin{tabular}{lcccrrc}
\hline Variable & August 8 & August 22 & September 5 & September 19 & SEM & $P$-value \\
\hline DM (\%) & $18^{\mathrm{a}}$ & $17^{\mathrm{ab}}$ & $16^{\mathrm{b}}$ & $15^{\mathrm{b}}$ & 6.2 & $<0.05$ \\
OM (g/kg of DM) & $926^{\mathrm{a}}$ & $907^{\mathrm{b}}$ & $927^{\mathrm{a}}$ & $924^{\mathrm{a}}$ & 13.1 & $<0.001$ \\
CP (g/kg of DM) & $186^{\mathrm{b}}$ & $237^{\mathrm{a}}$ & $191^{\mathrm{ab}}$ & $240^{\mathrm{a}}$ & 32.7 & $<0.05$ \\
NDF (g/kg of DM) & $481^{\mathrm{a}}$ & $419^{\mathrm{b}}$ & $416^{\mathrm{b}}$ & $457^{\mathrm{ab}}$ & 33.7 & $<0.05$ \\
ADF (g/kg of DM) & $309^{\mathrm{a}}$ & $254^{\mathrm{b}}$ & $256^{\mathrm{b}}$ & $299^{\mathrm{a}}$ & 20.9 & $<0.001$ \\
\hline
\end{tabular}

${ }^{\mathrm{a}, \mathrm{b}}$ Means within a row without a common superscript differ $(P<0.05)$. 
Table 5. The effect of dairy cow genotype $(\mathrm{n}=16$ per genotype) on milk yield and composition during in vivo digestibility studies conducted on 4 occasions in 2010 (weeks beginning August 8, August 22, September 5 , September 19)

\begin{tabular}{|c|c|c|c|c|c|}
\hline \multirow[b]{2}{*}{ Variable } & \multicolumn{3}{|c|}{ Genotype $^{1}$} & \multirow[b]{2}{*}{ SEM } & \multirow[b]{2}{*}{$P$-value } \\
\hline & $\mathrm{HF}$ & $\mathrm{JE}$ & $\mathrm{JE} \times \mathrm{HF}$ & & \\
\hline Milk yield (kg/d) & $16.93^{\mathrm{a}}$ & $12.81^{\mathrm{c}}$ & $15.33^{\mathrm{b}}$ & 0.449 & $<0.001$ \\
\hline Milk fat concentration $(\mathrm{g} / \mathrm{kg})$ & $56.7^{\mathrm{c}}$ & $76.9^{\mathrm{a}}$ & $64.7^{\mathrm{b}}$ & 2.11 & $<0.001$ \\
\hline Milk protein concentration $(\mathrm{g} / \mathrm{kg})$ & $34.3^{\mathrm{c}}$ & $39.6^{\mathrm{a}}$ & $36.6^{\mathrm{b}}$ & 0.62 & $<0.001$ \\
\hline Milk solids yield $(\mathrm{kg} / \mathrm{d})$ & 1.55 & 1.49 & 1.53 & 0.047 & NS \\
\hline $\mathrm{BW}(\mathrm{kg})$ & $576^{\mathrm{a}}$ & $434^{\mathrm{c}}$ & $501^{\mathrm{b}}$ & 8.65 & $<0.001$ \\
\hline Milk solids $(\mathrm{kg} / 100 \mathrm{~kg}$ of $\mathrm{BW})$ & $0.27^{\mathrm{c}}$ & $0.35^{\mathrm{a}}$ & $0.31^{\mathrm{b}}$ & 0.011 & $<0.001$ \\
\hline
\end{tabular}

capacity was not measured in the present study, but the reticulorumen weight was measured and it has been shown that a positive correlation exists between rumen capacity and rumen weight (Purser and Moir, 1966). In the present study, differences in reticulorumen weight as a proportion of BW are reflected in differences in GIT weight as a proportion of BW among genotypes. The proportionally heavier GIT found in JE in the present study, and also by Nagel and Piatkowski (1988), suggests that JE have a proportionally greater DMI capacity than HF. In the present study, a tendency for an effect of genotype on DMI capacity was noted, measured as DMI per BW. This is in contrast to a study by Smith and Baldwin (1974), who found no significant difference between JE and HF regarding proportional GIT weight. The study of Smith and Baldwin (1974) is, however, $40 \mathrm{yr}$ old, and the cows in that study, compared with modern dairy cow genetics, are likely to be considerably different. In the present study, JE $\times$ HF also had a proportionally (relative to $\mathrm{BW}$ ) greater reticulorumen and total GIT weight than $\mathrm{HF}$, which helps explain previous reports of a greater DMI capacity for the JE $\times$ HF compared with the HF (Prendiville et al., 2010; Xue et al., 2011; Vance et al., 2012) and supports the tendency for an effect of geno- type on DMI capacity measured in the present study. However, it should be noted that the omasum and intestinal tissues were weighed containing digesta and this may affect the differences observed. Herbage DMI is one of the most important factors influencing milk production in grazing dairy cows (Dillon, 2006). Kolver and Muller (1998) attributed the lower milk production of herbage-fed cows compared with TMR-fed cows to the lower DMI of the herbage-fed cows compared with cows offered TMR. The proportionally heavier GIT, and particularly the greater reticulorumen size, of JE and $\mathrm{JE} \times \mathrm{HF}$ compared with HF explains their greater intake capacity and is one biological difference that likely contributes to the previously reported production efficiency difference among these genotypes (Prendiville et al., 2009).

Increasing herbage allowance resulted in an increase in DMI and milk solids yield; this agrees with previous research (McEvoy et al., 2010). The topic of herbage allowance was not the main focus of the present study and will therefore not be discussed further.

Daily milk yield was higher for HF compared with both JE and JE $\times \mathrm{HF}$, and milk fat and protein concentration exhibited the opposite ranking order, agreeing with previous research (Heins et al., 2008; Prendiville et

Table 6. The effect of dairy cow genotype $(\mathrm{n}=16$ per genotype) on grass intake during in vivo digestibility studies conducted on 4 occasions in 2010 (weeks beginning August 8, August 22, September 5, September 19)

\begin{tabular}{lcccccc}
\hline & \multicolumn{3}{c}{ Genotype $^{1}$} \\
\cline { 2 - 3 } Variable & HF & JE & JE $\times$ HF & SEM & $P$-value \\
\hline DM intake $(\mathrm{kg} / \mathrm{d})$ & $16.71^{\mathrm{a}}$ & $13.93^{\mathrm{b}}$ & $15.96^{\mathrm{a}}$ & 0.165 & $<0.001$ \\
DM intake $(\mathrm{kg} / 100 \mathrm{~kg}$ of BW) & 2.98 & 3.22 & 3.09 & 0.054 & 0.08 \\
OM intake $(\mathrm{kg} / \mathrm{d})$ & $14.58^{\mathrm{a}}$ & $12.42^{\mathrm{b}}$ & $14.24^{\mathrm{a}}$ & 0.276 & $<0.001$ \\
N intake $(\mathrm{kg} / \mathrm{d})$ & $0.57^{\mathrm{a}}$ & $0.47^{\mathrm{b}}$ & $0.54^{\mathrm{a}}$ & 0.009 & $<0.001$ \\
NDF intake $(\mathrm{kg} / \mathrm{d})$ & $7.77^{\mathrm{a}}$ & $6.46^{\mathrm{b}}$ & $7.49^{\mathrm{a}}$ & & 0.111 & $<0.001$ \\
ADF intake $(\mathrm{kg} / \mathrm{d})$ & $4.29^{\mathrm{a}}$ & $3.58^{\mathrm{b}}$ & $4.15^{\mathrm{a}}$ & 0.061 & $<0.001$ \\
Milk solids $(\mathrm{kg} / \mathrm{kg}$ of DMI) & $0.093^{\mathrm{b}}$ & $0.108^{\mathrm{a}}$ & $0.096^{\mathrm{b}}$ & 0.003 & $<0.01$ \\
\hline
\end{tabular}

$\overline{\mathrm{a}, \mathrm{b}}$ Means within a row without a common superscript differ $(P<0.05)$.

${ }^{1} \mathrm{HF}=$ Holstein-Friesian; JE $=$ Jersey; JE $\times$ HF $=$ Jersey $\times$ Holstein-Friesian. 
Table 7. The effect of dairy cow genotype ( $\mathrm{n}=16$ per genotype) on apparent total-tract digestibility of grass during in vivo digestibility studies conducted on 4 occasions in 2010 (weeks beginning August 8, August 22, September 5, September 19)

\begin{tabular}{|c|c|c|c|c|c|}
\hline \multirow[b]{2}{*}{ Variable (\%) } & \multicolumn{3}{|c|}{ Genotype $^{1}$} & \multirow[b]{2}{*}{ SEM } & \multirow[b]{2}{*}{$P$-value } \\
\hline & $\mathrm{HF}$ & $\mathrm{JE}$ & $\mathrm{JE} \times \mathrm{HF}$ & & \\
\hline DM digestibility & $78.8^{\mathrm{a}}$ & $80.6^{\mathrm{b}}$ & $79.0^{\mathrm{a}}$ & 0.44 & $<0.01$ \\
\hline OM digestibility & $79.5^{\mathrm{a}}$ & $81.7^{\mathrm{b}}$ & $80.6^{\mathrm{ab}}$ & 0.40 & $<0.01$ \\
\hline $\mathrm{N}$ digestibility & $79.8^{\mathrm{a}}$ & $82.4^{\mathrm{b}}$ & $81.0^{\mathrm{ab}}$ & 0.53 & $<0.01$ \\
\hline NDF digestibility & $78.6^{\mathrm{a}}$ & $81.0^{\mathrm{b}}$ & $79.6^{\mathrm{ab}}$ & 0.52 & $<0.05$ \\
\hline ADF digestibility & $70.5^{\mathrm{a}}$ & $74.4^{\mathrm{b}}$ & $72.2^{\mathrm{ab}}$ & 1.05 & $<0.01$ \\
\hline
\end{tabular}

${ }_{\mathrm{a}, \mathrm{b}}$ Means within a row without a common superscript differ $(P<0.05)$.

${ }^{1} \mathrm{HF}=$ Holstein-Friesian; $\mathrm{JE}=$ Jersey; $\mathrm{JE} \times \mathrm{HF}=$ Jersey $\times$ Holstein-Friesian.

al., 2009; Olson et al., 2010). Milk solids per BW were lower for HF than for either JE or JE $\times$ HF. These differences have been discussed by the aforementioned authors in detail and are presented in the present study for the purpose of confirmation only; therefore, these results will not be discussed herein.

Digestibility is expected to decrease with increasing DMI due to a faster rate of passage (Thornton and Minson, 1972; Tyrrell and Moe, 1975). Equally, a lower DMI is associated with a slower rate of passage and is expected to increase digestibility (Tyrrell and Moe, 1975). The present study and previous studies have shown that JE have a greater DMI as a proportion of BW (Goddard and Grainger, 2004; Prendiville et al., 2009); accordingly, Ingvartsen and Weisbjerg (1993) and Aikman et al. (2008) reported that JE had a faster rate of passage than $\mathrm{HF}$, thus it would be expected that JE would have a lower digestive efficiency than HF. However, the present study found that JE were more efficient for all digestive parameters measured, which may be partly attributed to the relatively larger GIT of the JE. Increased relative GIT size indicates a relatively larger area available for absorption of nutrients, allowing for greater nutrient absorption and, thus, increased digestibility (Van Soest, 1994). Additionally, research has shown a simultaneous increase in digestibility and intake on high-quality, herbage-only diets (Baumont et al., 2007). The differences in digestibility among genotypes are in contrast with previous studies that found no difference in DM digestibility among dairy breeds offered corn silage (Blake et al., 1986) or a TMR diet (Ingvartsen and Weisbjerg, 1993). Diet type (e.g., high vs. low forage) can greatly affect passage rates and diet digestibility, however (Colucci et al., 1982). Therefore, passage rates among dairy cow genotypes should be investigated further with cows offered a high-quality herbage diet to determine if differences among genotypes exist.

The higher digestibility exhibited by JE cows may also be explained by their greater number and frequen- cy of grazing and ruminating mastications compared with HF (Prendiville et al., 2010). Mastication plays a part in digestion by physically disrupting the food and breaking it into smaller particles to facilitate microbial attack (McAllister et al., 1994). This would result in smaller particles entering the JE rumen, which are potentially digested more rapidly (Fritz et al., 2009).

The increased fiber digestibility observed in the JE further confirms that they are well suited to grazing systems, as herbage typically contains more fiber and less energy than concentrate feeds (Hendy et al., 1995; O'Mara, 2000; Coleman et al., 2010). Aikman et al. (2008) found differences between $\mathrm{HF}$ and JE regarding NDF digestibility of a TMR diet, consistent with the present study. Unlike the present study, however, Aikman et al. (2008) observed no differences among genotypes regarding ADF digestibility. The ADF digestibility values in the present study are higher than the values reported by Aikman et al. (2008), but the diet in that study was a TMR, compared with herbage in the present study.

In the present study, JE had a greater $\mathrm{N}$ digestibility than HF, this was likely of no benefit to the JE, as N was not limiting in the high-CP grass diet being offered. Generally, in herbage-based diets, energy intake is the factor most limiting to animal performance (O'Mara, 2000), and therefore the increased OM digestibility is of greater significance, although the increased N digestibility is a contributor to this. Blake et al. (1986) found no difference between $\mathrm{JE}$ and $\mathrm{HF}$ regarding $\mathrm{N}$ digestibility during the first trimester of lactation, although JE had a higher $\mathrm{N}$ digestibility than HF in the second trimester of lactation. No difference was observed in $\mathrm{N}$ digestibility between $\mathrm{HF}$ and $\mathrm{JE} \times \mathrm{HF}$, which was also found by Xue et al. (2011).

Increasing the digestibility of a feed means that more of the feed is used and less is excreted as waste product. This will result in increased energy available to the animal. The present study shows that a difference exists among breeds in total-tract digestibility. The JE had a 
higher total-tract digestibility, indicating an increase in energy available for milk solids production (Coulon and Rémond, 1991). This increase in total-tract digestibility likely contributes to the difference in milk production efficiency measured among these dairy cow genotypes (Prendiville et al., 2010). The JE were able to digest $2.2 \%$ more of the grass than HF, which is the equivalent of an increase in the energy content of grass from 1.01 to 1.05 unite fourragère lait $/ \mathrm{kg}$ of $\mathrm{DM}$. One unite fourragère lait of energy is defined as the net energy content of $1 \mathrm{~kg}$ of standard barley for milk production, which is $1,700 \mathrm{kcal}$. This increases the energy available for milk production for JE by 0.56 unite fourragère lait per day. This corresponds to JE being able to produce an extra $0.90 \mathrm{~kg}$ of milk per day (39.6 g of protein $/ \mathrm{kg}$, $76.9 \mathrm{~g}$ of fat $/ \mathrm{kg})$.

Rumen microorganisms, particularly cellulolytic bacteria, protozoa, and fungi, are critically important for the fermentation of feed (Van Soest, 1994; Gordon and Phillips, 1998) into short-chain FA, including propionate, acetate, butyrate, lactate, and succinate (Hungate, 1966). These serve as major carbon and energy sources for the ruminant. It is widely accepted that diet has a role to play in shaping the microbial communities of the rumen (de Menezes et al., 2011; Carberry et al., 2012; Boots et al., 2013). Typically animals on foragebased diets will have more fibrolytic bacteria and less starch-digesting amylolytic bacteria than animals on a starch-based diet (Van Soest, 1994; Beever and Mould, 2000). All 3 genotypes had similar abundance of protozoa, anaerobic fungi, and F. succinogenes; however, JE cows had a reduced abundance of $R$. flavefaciens compared with HF and JE $\times$ HF. This cellulolytic bacterial species is associated with fiber digestion in the rumen (Baldwin and Allison, 1983; Van Soest, 1994). Despite this, JE cows had a higher NDF and ADF digestibility than HF cows. Differences in NDF and ADF digestibility may be due to differences in microbial populations that were not evaluated in the present study. A more comprehensive approach, such as sequencing of rumen metagenomic DNA, may uncover differences responsible for the observed differences in fiber digestibility and may also provide evidence for other biological differences among the dairy cow genotypes.

\section{CONCLUSIONS}

Earlier studies demonstrated that modern JE genetics are well suited to herbage-based systems because of their ability to achieve high herbage intakes and efficiently convert herbage to milk solids. Conclusions from the current study are that the JE genotype has greater digestibility and a different rumen microbial population than HF. Jersey and JE $\times$ HF cows had a proportionally greater GIT weight than HF. These differences are likely to contribute to the production efficiency differences among genotypes previously reported.

\section{ACKNOWLEDGMENTS}

The authors acknowledge the technical assistance of B. O'Loughlin, G. Hanrahan, N. Galvin, C. Fleming and the Teagasc Moorepark farm staff. The technical assistance of J. Larkin, Teagasc, Animal and Bioscience Department, Grange is also acknowledged.

\section{REFERENCES}

Abattoirs Act. 1988 Regulations. 1999. Abattoirs Act, 1988 (Abattoirs) (Amendment) Regulations, 1999. S.I. No. 328/1999. Accessed Mar. 20, 2014. http://www.irishstatutebook.ie/1999/en/ si/0328.html.

Aikman, P. C., C. K. Reynolds, and D. E. Beever. 2008. Diet digestibility, rate of passage, and eating and rumination behavior of Jersey and Holstein cows. J. Dairy Sci. 91:1103-1114.

Allen, M. S. 1996. Physical constraints on voluntary intake of forages by ruminants. J. Anim. Sci. 74:3063-3075.

Allison, C. D. 1985. Factors affecting forage intake by range ruminants: A review. J. Range Manage. 38:305-311.

AOAC International. 1995. Official Methods of Analysis. 16th ed. P. Cunniff, ed. AOAC International, Arlington, VA

Baldwin, R. L., and M. J. Allison. 1983. Rumen metabolism. J. Anim. Sci. 57(Suppl. 2):461-477.

Baumont, R., J. Dulphy, D. Sauvant, F. Meschy, J. Aufrère, and J. Peyraud. 2007. Valeur alimentaire des fourrages et des matières premières: Tables et prévision. Pages 149-179 in Alimentation des Bovins, Ovins et Caprins. Besoins des Animaux-Valeurs des Aliments. Editions QUAE, Versailles, France.

Beever, D. E., and F. L. Mould. 2000. Forage evaluation for efficient ruminant livestock production. Pages $15-42$ in Forage Evaluation in Ruminant Nutrition. D. I. Givens, E. Owen, R. F. E. Axford, and H. M. Omed, ed. CABI Publishing, Wallingford, UK.

Berry, D. P., and J. Crowley. 2013. Genetics of feed efficiency in dairy and beef cattle. J. Anim. Sci. 91:1594-1613.

Berry, D. P., B. Horan, M. O'Donovan, F. Buckley, E. Kennedy, M. McEvoy, and P. Dillon. 2007. Genetics of grass dry matter intake, energy balance, and digestibility in grazing Irish dairy cows. J. Dairy Sci. 90:4835-4845.

Blake, R. W., A. A. Custodio, and W. H. Howard. 1986. Comparative feed efficiency of Holstein and Jersey cows. J. Dairy Sci. 69:1302-1308

Boots, B., L. Lillis, N. Clipson, K. Petrie, D. A. Kenny, T. M. Boland, and E. Doyle. 2013. Responses of anaerobic rumen fungal diversity (phylum Neocallimastigomycota) to changes in bovine diet. J. Appl. Microbiol. 114:626-635.

Buckley, F., B. Horan, N. Lopez-Villalobos, and P. Dillon. 2007. Milk production efficiency of varying dairy cow genotypes under grazing conditions. Pages 74-83 in Meeting the Challenges for PastureBased Dairying. Proc. 3rd Dairy Sci. Symp., University of Melbourne, Victoria, Australia. University of Melbourne, Melbourne, Victoria, Australia.

Bustin, S. A., V. Benes, J. A. Garson, J. Hellemans, J. Huggett, M. Kubista, R. Mueller, T. Nolan, M. W. Pfaffl, G. L. Shipley, J. Vandesompele, and C. T. Wittwer. 2009. The MIQE guidelines: Minimum information for publication of quantitative real-time PCR experiments. Clin. Chem. 55:611-622.

Carberry, C. A., D. A. Kenny, S. Han, M. S. McCabe, and S. M. Waters. 2012. Effect of phenotypic residual feed intake and dietary forage content on the rumen microbial community of beef cattle. Appl. Environ. Microbiol. 78:4949-4958. 
Chen, X. L., J. K. Wang, Y. M. Wu, and J. X. Liu. 2008. Effects of chemical treatments of rice straw on rumen fermentation characteristics, fibrolytic enzyme activities and populations of liquid- and solid-associated ruminal microbes in vitro. Anim. Feed Sci. Technol. 141:1-14.

Coleman, J., K. M. Pierce, D. P. Berry, A. Brennan, and B. Horan. 2010. Increasing milk solids production across lactation through genetic selection and intensive pasture-based feed system. J. Dairy Sci. 93:4302-4317.

Colucci, P. E., L. E. Chase, and P. J. Van Soest. 1982. Feed intake, apparent diet digestibility, and rate of particulate passage in dairy cattle. J. Dairy Sci. 65:1445-1456.

Connor, E. E., J. L. Hutchison, H. D. Norman, K. M. Olson, C. P. Van Tassell, J. M. Leith, and R. L. Baldwin. 2013. Use of residual feed intake in Holsteins during early lactation shows potential to improve feed efficiency through genetic selection. J. Anim. Sci. 91:3978-3988.

Coulon, J., and B. Rémond. 1991. Variations in milk output and milk protein content in response to the level of energy supply to the dairy cow: A review. Livest. Prod. Sci. 29:31-47.

Cruelty to Animals Act. 1876. Accessed Mar. 20, 2014. http://www. irishstatutebook.ie/1876/en/act/pub/0077/print.html.

de Menezes, A. B., E. Lewis, M. O'Donovan, B. F. O'Neill, N. Clipson, and E. M. Doyle. 2011. Microbiome analysis of dairy cows fed pasture or total mixed ration diets. FEMS Microbiol. Ecol. $78: 256-265$.

Dillon, P. 2006. Achieving high dry matter intake from pasture with dairy cows. Pages 1-26 in Proc. Fresh Herb. Dairy Cattle. Springer, Houten, the Netherlands.

Fritz, J., J. r. Hummel, E. Kienzle, C. Arnold, C. Nunn, and M. Clauss. 2009. Comparative chewing efficiency in mammalian herbivores. Oikos 118:1623-1632.

Geishauser, T., N. Linhart, A. Neidl, and A. Reimann. 2012. Factors associated with ruminal $\mathrm{pH}$ at herd level. J. Dairy Sci. 95:45564567.

Goddard, M. E., and C. Grainger. 2004. A review of the effects of dairy breed on feed conversion efficiency-An opportunity lost? Anim. Prod. Aust. 1:77-80.

Gordon, G. L., and M. W. Phillips. 1998. The role of anaerobic gut fungi in ruminants. Nutr. Res. Rev. 11:133-168.

Guan, L. L., J. D. Nkrumah, J. A. Basarab, and S. S. Moore. 2008. Linkage of microbial ecology to phenotype: Correlation of rumen microbial ecology to cattle's feed efficiency. FEMS Microbiol. Lett. 288:85-91.

Guo, Y. Q., J. X. Liu, Y. Lu, W. Y. Zhu, S. E. Denman, and C. S. McSweeney. 2008. Effect of tea saponin on methanogenesis, microbial community structure and expression of $m c r A$ gene, in cultures of rumen microorganisms. Lett. Appl. Microbiol. 47:421-426.

Heins, B. J., L. B. Hansen, A. J. Seykora, A. R. Hazel, D. G. Johnson, and J. G. Linn. 2008. Crossbreds of Jersey $\times$ Holstein compared with pure Holsteins for body weight, body condition score, dry matter intake, and feed efficiency during the first one hundred fifty days of first lactation. J. Dairy Sci. 91:3716-3722.

Hendy, C., U. Kleih, R. Crawshaw, and M. Phillips. 1995. Livestock and the Environment: Finding a Balance: Interactions Between Livestock Production Systems and the Environment: Impact Domain: Concentrate Feed Demand. Natural Resources Institute, Chatham, UK.

Hogan, J., and R. Weston. 1967. The digestion of chopped and ground roughages by sheep. II. Digestion of nitrogen and some carbohydrate fractions in the stomach and intestines. Aust. J. Agric. Res. 18:803-819.

Hungate, R. E. 1966. The Rumen and its Microbes. Acad. Press, New York, NY

Ingvartsen, K., and M. Weisbjerg. 1993. Jersey cows have a higher feed intake capacity and higher rate of passage than Friesian cows. Archiv. Fuer. Tierzucht. 5:495-498.

Kolver, E. S., and L. D. Muller. 1998. Performance and nutrient intake of high producing Holstein cows consuming pasture or a total mixed ration. J. Dairy Sci. 81:1403-1411.
Lopez-Villalobos, N., D. Berry, B. Horan, F. Buckley, J. Kennedy, M. O'Donovan, L. Shalloo, and P. Dillon. 2008. Genetics of residual energy intake in Irish grazing dairy cows. Proc. N.Z. Soc. Anim. Prod. 68:97-100.

McAllister, T. A., H. D. Bae, G. A. Jones, and K. J. Cheng. 1994. Microbial attachment and feed digestion in the rumen. J. Anim. Sci. 72:3004-3018.

McEvoy, M., L. Delaby, J. P. Murphy, T. M. Boland, and M. O'Donovan. 2010. Effect of herbage mass and allowance on sward characteristics, milk production, intake and rumen volatile fatty acid concentration. Grass Forage Sci. 65:335-347.

Nagel, S., and B. Piatkowski. 1988. Zur messung des Pansenvolumen von Jersey Kühen. Arch. Tierzucht 31:43-45.

O'Loughlin, A., M. McGee, S. Waters, S. Doyle, and B. Earley. 2011. Examination of the bovine leukocyte environment using immunogenetic biomarkers to assess immunocompetence following exposure to weaning stress. BMC Vet. Res. 7:45.

O'Mara, F. P. 2000. A Net Energy System for Cattle and Sheep. Version 1.2. University College, Dublin, Ireland.

Olson, K. M., B. Cassell, and M. Hanigan. 2010. Energy balance in first-lactation Holstein, Jersey, and reciprocal $F_{1}$ crossbred cows in a planned crossbreeding experiment. J. Dairy Sci. 93:4374-4385.

Pfaffl, M. W. 2001. A new mathematical model for relative quantification in real-time RT-PCR. Nucleic Acids Res. 29:e45.

Prendiville, R., E. Lewis, K. M. Pierce, and F. Buckley. 2010. Comparative grazing behavior of lactating Holstein-Friesian, Jersey, and Jersey $\times$ Holstein-Friesian dairy cows and its association with intake capacity and production efficiency. J. Dairy Sci. 93:764-774.

Prendiville, R., K. M. Pierce, and F. Buckley. 2009. An evaluation of production efficiencies among lactating Holstein-Friesian, Jersey, and Jersey $\times$ Holstein-Friesian cows at pasture. J. Dairy Sci. 92:6176-6185.

Prendiville, R., K. M. Pierce, L. Delaby, and F. Buckley. 2011a. Animal performance and production efficiencies of Holstein-Friesian, Jersey and Jersey $\times$ Holstein-Friesian cows throughout lactation. Livest. Sci. 138:25-33.

Prendiville, R., L. Shalloo, K. Pierce, and F. Buckley. 2011b. Comparative performance and economic appraisal of Holstein-Friesian, Jersey and Jersey $\times$ Holstein-Friesian cows under seasonal pasture-based management. Ir. J. Agric. Food Res. 50:123-140.

Purser, D. B., and R. J. Moir. 1966. Rumen volume as a factor involved in individual sheep differences. J. Anim. Sci. 25:509-515.

Raymond, W. F., C. E. Harris, and V. G. Harker. 1953. Studies on the digestibility of herbage. Grass Forage Sci. 8:301-314.

Richardson, E., and R. Herd. 2004. Biological basis for variation in residual feed intake in beef cattle. 2. Synthesis of results following divergent selection. Anim. Prod. Sci. 44:431-440.

Rymer, C. 2000. The measurement of forage digestibility in vivo. Pages 113-134 in Forage Evaluation in Ruminant Nutrition. D I. Givens, E. Owen, R. F. E. Axford, and H. M. Omed, ed. CABI Publishers, New York, NY.

Smith, N. E., and R. L. Baldwin. 1974. Effects of breed, pregnancy, and lactation on weight of organs and tissues in dairy cattle. J. Dairy Sci. 57:1055-1060.

Spurlock, D. M., J. C. M. Dekkers, R. Fernando, D. A. Koltes, and A. Wolc. 2012. Genetic parameters for energy balance, feed efficiency, and related traits in Holstein cattle. J. Dairy Sci. 95:5393-5402.

Svendsen, M., P. Skipenes, and I. Mao. 1993. Genetic parameters in the feed conversion complex of primiparous cows in the first two trimesters. J. Anim. Sci. 71:1721-1729.

Thackaberry, C., T. M. Boland, K. M. Pierce, and F. Buckley. 2011. A comparison of Holstein-Friesian, Jersey and Jersey $\times$ Holstein Friesian dairy cows under varying stocking rates. Page 107 in Irel. Agric. Res. Forum. Tullamore, Co. Offaly, Ireland. Teagasc, Oak Park, Carlow, Ireland

Thornton, R. F., and D. J. Minson. 1972. The relationship between voluntary intake and mean apparent retention time in the rumen. Aust. J. Agric. Res. 23:871-877.

Tyrrell, H., and P. Moe. 1975. Effect of intake on digestive efficiency. J. Dairy Sci. 58:1151-1163. 
Van Soest, P. J., J. B. Robertson, and B. A. Lewis. 1991. Methods for dietary fiber, and nonstarch polysaccharides in relation to animal nutrition. J. Dairy Sci. 74:3583-3597.

Van Soest, P. J. 1994. Nutritional Ecology of the Ruminant. O \& B Books Inc., Corvallis, OR.

Vance, E., C. Ferris, C. Elliott, and D. Kilpatrick. 2012. A comparison of the feeding and grazing behaviour of primiparous HolsteinFriesian and Jersey $\times$ Holstein-Friesian dairy cows. Ir. J. Agric. Food Res. 51:45-61.

Veerkamp, R., G. Emmans, A. Cromie, and G. Simm. 1995. Variance components for residual feed intake in dairy cows. Livest. Prod. Sci. 41:111-120.

Weimer, P. J., G. Waghorn, C. Odt, and D. Mertens. 1999. Effect of diet on populations of three species of ruminal cellulolytic bacteria in lactating dairy cows. J. Dairy Sci. 82:122-134.
Wilkinson, J. M. 2011. Re-defining efficiency of feed use by livestock. Animal 5:1014-1022.

Williams, A. G., and G. Coleman. 1997. The rumen protozoa. Pages 73-179 in The Rumen Microbial System. Hobson, Springer-Verlag New York Inc., New York, NY.

Xue, B., T. Yan, C. Ferris, and C. Mayne. 2011. Milk production and energy efficiency of Holstein and Jersey-Holstein crossbred dairy cows offered diets containing grass silage. J. Dairy Sci. 94:14551464.

Yu, Z., and M. Morrison. 2004. Improved extraction of PCR-quality community DNA from digesta and fecal samples. Biotechniques 36:808-812. 